\title{
Remote Sensing Assessment of Biomass Evolution Depending on Forest Management ${ }^{\dagger}$
}

\author{
David Vinué-Visús *, Eloína Coll-Aliaga and José-Vicente Oliver-Villanueva \\ ITACA Institute, Universitat Politècnica de València, 46022 Valencia, Spain \\ * Correspondence: davivi1@upv.es \\ † Presented at the II Congress in Geomatics Engineering, Madrid, Spain, 26-27 June 2019. \\ Published: 12 July 2019
}

\begin{abstract}
Remote sensing and advanced statistical models have been used to assess actual biomass and to analyze the biomass growth in a mature forest of Pinus halepensis Mill. Biomass maps using Landsat-5 in 2011 and Landsat-8 imagery in 2017 and non-parametric models were achieved. Afterwards, a fast and affordable methodology has been developed to monitor the evolution depending on forest management or its abandonment. Significative statistical evidences have been found between two types of management, demonstrating that managed areas have bigger growth potential. This methodology spares the efforts of exhaustive inventories and encourage forest managers to maximize their forest allowances.
\end{abstract}

Keywords: remote sensing; biomass evolution; forest management; statistics

\section{Introduction}

Forest in the Mediterranean area of Spain had a traditional lack of management during the last decades and only a few hectares of forest have an active management plan [1]. Nevertheless, Mediterranean forest structures and species have high photosynthetic capacities and net primary productivity (NPP) comparable to other more valued biomes [2]. Consequently, actual low carbon stock in Mediterranean forest is more dependent on socioeconomics than on ecology conditions [3].

The aim of this study is to analyze the effects of forest management in the biomass growth in a Mediterranean forest to settle the best practices in mature forest to maximize the carbon sequestration. For this purpose, reflectance values of two satellite images have been processed, allometric equations have been deployed over two reduced forest inventories and using nonparametric methods maps of biomass of 2011 and 2017 have been created. Afterwards, a KruskalWallis analysis have been performed over data obtained in areas with a forest management and over those ones with a lack of management.

\section{Material and Methods}

\subsection{Area of Study and Forest Inventories}

The area of study is in the Municipality of Enguera (Spain), where 5.65 ha of a mature forest of Pinus halepensis Mill. were managed after an experimental design for biomass exploitation [4] Inventories registered for this management were performed in 2011. Afterwards, in 2017 a new forest inventory was done selecting randomly managed and not managed areas. Methodology of both inventories follow the guidelines of the 3rd National Forest Inventory [5]. 


\subsection{Allometric Equations}

Using diameter-at-breast-height and total height values of the measured trees as inputs, allometric equations where used to calculate total biomass [6].

\subsection{Satellite Imagery}

Two Landsat images have been used to deploy a biomass map of the area of study in 2011 and 2017. Both images are close the summer solstitial to cancel angular differences between them. Landsat-5 TM for 2011 and Landsat-8 OLI sensors where used, due its availability. These images provide pixels within $30 \mathrm{~m}$ of spatial resolution and have been downloaded corrected till surface reflectance values [7].

\subsection{Biomass Assessment and Growth}

For biomass assessment and to generate a regional biomass map using only a few numbers of field data, Gaussian-process non-parametric regression methods have been applied over Landsat surface reflectance and forest inventories data [8]. Results are good enough to monitor a forest management and the methodology is affordable in terms of time, cost, efforts and computing capacity.

Finally, pixels of managed and not managed areas where randomly selected to compare the differences in the evolution of the biomass between 2011 and 2017. Differences of biomass generated a database with growth biomass values.

\subsection{Statistical Analysis}

A descriptive analysis of the growth biomass values has performed. To compare these values and to find if there is a significative difference between forest managements, analysis of normality and homocedasticity to validate the equality of variances have been performed. A comparative of the variances will indicate if it exists any difference between data.

\section{Results and Discussion}

\subsection{Maps of Biomass, 2011-2017}

Two maps after applying Gaussian-process have been obtained. Biomass acted as dependent variable and reflectance values of R, G, B, NIR, SWIR1 and SWIR2 acted as independent variables. A resulting map of differences indicates the growth biomass, and SIG segmentation indicates managed and not-managed areas.

\subsection{Data Analysys}

\subsubsection{Description of the Biomass Evolution}

Randomly extracted, data for both type of forest is included in the Table 1.

Table 1. Statistics of the growth biomass values $\left(\mathrm{Mg} \mathrm{ha}^{-1}\right)$ for both managed and not managed forests.

\begin{tabular}{ccccccc}
\hline Forest & Minimum & 1st Quartile & Median & Mean & 3rd Quartile & Maximum \\
\hline Managed & 3.135 & 8.692 & 11.099 & 10.235 & 13.774 & 14.559 \\
Not managed & 3.128 & 4.339 & 4.980 & 6.342 & 7.310 & 12.77 \\
\hline
\end{tabular}

Managed forest sampling has a normal distribution, with no skew, where median and mean are almost coinciding (11.099 and $10.235 \mathrm{Mg} \mathrm{ha}^{-1}$, respectively) and differences between median and first and third quartile (2.407 and $2.675 \mathrm{Mg} \mathrm{ha}^{-1}$, respectively) close to a positive skewed distribution with a low magnitude of significance. 
For those not managed forest sampling, mean $\left(6.342 \mathrm{Mg} \mathrm{ha}^{-1}\right)$ is slightly higher than median $\left(4.980 \mathrm{Mg} \mathrm{ha}^{-1}\right)$ although not bigger than \pm 2 and difference between median a third quartile $(2.33 \mathrm{Mg}$ $\left.\mathrm{ha}^{-1}\right)$ is higher than the difference between median and first quartile $\left(0.641 \mathrm{Mg} \mathrm{ha}^{-1}\right)$. As a result, mature forest has a slightly right, positive skewed distribution, but close to a normal distribution.

Skewness for both samples (-0.617 and 0.952) and kurtosis $(-1.226$ and -0.529 for managed and not managed forest, respectively) indicate that samples are normally distributed. Alternatively, Kolmogorov-Smirnov test confirms the normality of the samples.

However, a slightly evidence of asymmetry is shown by inventories of not managed forests, most probably due two outliers of the sample, as shown in Figure 1a. To ensure the description of the database, an analysis has been performed over the global biomass growth database (Table 2).

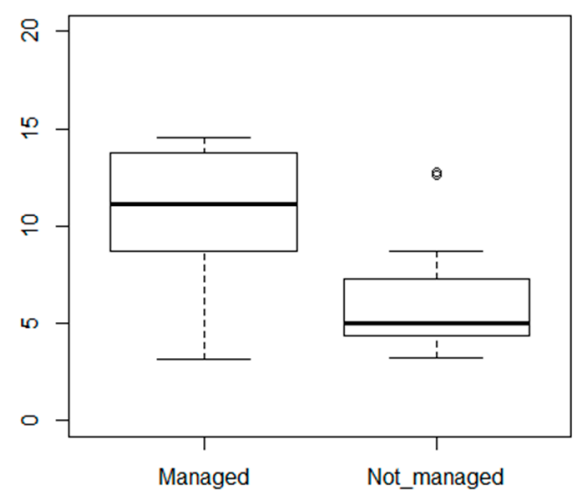

(a)

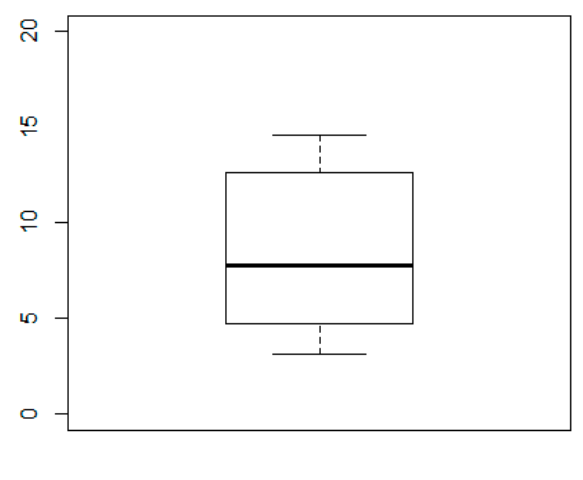

(b)

Figure 1. Graphic depicting of databases: (a) indicates values of biomass increasement sampled in managed and not managed forests, with some anomalies detected for higher biomass values of not managed forests; (b) performs of a joint database obtained after inventories, where a positive skewed distribution can be noticed.

Table 2. Statistics of the growth biomass values $\left(\mathrm{Mg} \mathrm{ha}^{-1}\right)$. 2011-2017. A general overview.

\begin{tabular}{ccccccc}
\hline Forest & Minimum & 1st Quartile & Median & Mean & 3rd Quartile & Maximum \\
\hline Inventory & 3.135 & 4.748 & 7.787 & 8.258 & 12.551 & 14.559 \\
\hline
\end{tabular}

For a global database skewness (0.211) and kurtosis (-1.597) indicates that samples are normally distributed but Kolmogorov-Smirnov test (0.382) is highly reduced compared with the previous analysis. But after a negative test of Saphiro, where $\mathrm{H}_{0}$ cannot be rejected, and after an analysis of Figure $1 b$, normality of the database must not be assumed.

Homocedasticity has been tested via Bartlett's test to analyze the homogeneity of the variances. After regretting $\mathrm{H}_{0}$ and verifying the alternative hypothesis, equality of variances can be assumed.

\subsubsection{Test de Kruskal-Wallis}

As normality cannot be assumed, a pseudo-ANOVA for non-normal data Kruskal-Wallis test for two sampling has been performed. Together whit a validation of the alternative hypothesis $\mathrm{H}_{1}$, it indicates that forest management is responsible of a growth variability between $25 \%$ and $99 \%$, enough to conclude the significant effect of a forest management.

\subsection{Discussion}

Remote sensing-based maps are enough accurate to detect biomass evolution on Mediterranean forests. A positive influence of the forest management in the biomass growth can be assumed, although due the natural variability of the forest some plots of unmanaged forest have had unusual development. These outliers created a lack of normality in the data, but even with this determinant means of biomass growth after six years are noticeable. This study has been performed over 
homogeneous forest areas in a Köppen-Geiger Csa area and external, non-managed conditions of the experiment design have been similar for any of the plots analyzed. However, an extended study including a multivariate analysis could be done to settle the most restrictive and permissive climate and topographic factors affecting the biomass growth.

\section{Conclusions}

Remote sensing and advanced statistical models have been successfully used for biomass assessment and biomass increasement monitor after a medium-period of time within a fast and affordable methodology. Enough significative statistical evidences have been found to affirm that a sustainable forest management in Mediterranean areas increase the biomass growth and the subsequent carbon sequestration. Although this management have been performed in a later stage of the forest, a significant improvement has been detected.

Managed areas, conditions of the forest and intensity of the forest managements have been not performed as a designed experiment, but remote sensing helped to monitor the evolution of the biomass. For that reason, further studies should be designed defining other areas and managements to evaluate.

Author Contributions: Conceptualization, D.V.-V. and J.V.O.-V.; methodology, J.V.O.-V.; software, D.V.-V.; validation, E.C.-A.; formal analysis, D.V.-V.; investigation, D.V.-V.; writing original draft preparation, D.V.-V.; writing-review and editing, J.V.O.-V. and E.C.-A.; supervision, J.V.O.-V. and E.C.-A; project administration, J.V.O.V.

Funding: This research received no external funding.

Conflicts of Interest: The authors declare no conflict of interest and the funders had no role in the design of the study; in the collection, analyses, or interpretation of data; in the writing of the manuscript, or in the decision to publish the results.

\section{References}

1. PATFOR: Plan de Acción Territorial Forestal de la Comunitat Valenciana; Generalitat Valenciana; Conselleria de Infraestructuras, Territorio y Medio Ambiente, Valencia, Spain; Decreto 58/2013, de 3 de mayo, del Consell, por el que se aprueba el Plan de Acción Territorial Forestal de la Comunitat Valenciana. [2013/4617]. DOGV Ed.: Valencia, Spain; p. 35

1. Flexas, J.A.; Diaz-Espejo, A.; Gago, J.; Gallé, A.; Galmés, J.; Gulías, J.; Medrano, H. Photosynthetic limitations in Mediterranean plants: A review. Environ. Exp. Bot. 2014, 103, 12-23.

2. Galidaki, G.; Zianis, D.; Gitas, I.; Radoglou, K.; Karathanassi, V.; Tsakiri-Strati, M.; Woodhouse, I.; Mallinis, G. Vegetation biomass estimation with remote sensing: Focus on forest and other wooded land over the Mediterranean ecosystem. Int. J. Remote Sens. 2017, 38, 1940-1966, doi:10.1080/01431161.2016.1266113.

3. Lerma Arce, V. Planificación, Logística y Valorización de Biomasa Forestal Residual en la Provincia de Valencia. Ph.D. Thesis, Universitat Politècnica de València, Valencia, Spain, 2015; doi:10.4995/Thesis/10251/52391.

4. III Inventario Forestal Nacional Español 1996-2006. Direccion General de Conservacion de la Naturaleza; Ministerio de Medio Ambiente: Madrid, Spain, 2006.

5. Ruiz-Peinado, R.; del Río, M.; Montero, G. New models for estimating the carbon sink capacity of Spanish softwood species. For. Syst. 2011, 20, 176-188.

6. U.S. Geological Survey. Available online: https://earthexplorer.usgs.gov/ (accessed on 15 November 2018).

7. Vinué-Visús, D.; Camacho, F.; Oliver-Villanueva, J.V.; Coll-Aliaga, E. Estimación de la biomasa de Pinus halepensis Mill. con imágenes Sentinel-2 y máquinas de aprendizaje automático en un contexto de cambio climático. In Proceedings of the III Congreso Forestal de la Comunitat Valenciana, Valencia, Spain, 15-16 November 2018; Universitat de València ed. pp. 48-64. 